\title{
Should Europe Worry About Adversarial Legalism?
}

\author{
ROBERT A. KAGAN*
}

National legal systems are very complicated creatures, resistant to simple generalizations, and in democratic nations, they surely have more shared features than divergent ones. I have argued, however, that compared to other constitutional democracies, policy implementation and dispute resolution in the United States are distinctive in the degree to which those processes are pervaded by adversarial legal contestation. ${ }^{1}$ In response, some observers argue that the rest of the economically developed world is moving inexorably toward convergence with American adversarial legalism, pushed in that direction by more competitive global markets, the weakening of the welfare state, and the growth of transnational European government. That 'convergence' argument raises the broad questions addressed in this essay:

1. What are the prospects that Western European countries eventually will trade in their orderly legal systems for a high-horsepower but expensive and hard-tocontrol American model?

2. More fundamentally, what are the dynamics of systemic legal change? To what extent can national legal cultures remain autonomous from changes in political and economic systems?

I cannot even pretend to provide definitive answers, either to the predictive empirical question or to the theoretical ones. But the effort to discuss them, I hope, will stimulate some useful thought.

I will focus primarily on what I am most familiar with-the forces that have intensified adversarial legalism in the United States. Many of those forces, it will emerge, have certain parallels in Europe, suggesting there are theoretical reasons to expect adversarial legalism to increase, both on the Continent and in the United Kingdom. But after assessing the dynamics toward convergence, I ultimately will argue that American-style adversarial legalism will not blossom

\footnotetext{
* Cunter for the Study of Law and Society, University of Califomia, Berkeley, CA, USA. This article is based on the author's Inaugural Annual Lecture, Centre for Socio-Legal Studies, Oxford University, 5 May 1995.

1 Robert A. Kagan, 'Adversarial Legalism and American Government', in Marc K. Landy \& Martin A. Levin, $T h \cdot N_{i}$ is Politici of Public Policy (Baltimore and London: Johns Hopkins University Press, 1995). See also Kagan, 'Do Lawyers Cause Adversarial Legalism? A Preliminary Inquiry', 19 Law E Social Inquiry, 1-62 (1994).
} 
all over Europe. The cultural soil, both legal and political, is not fully hospitable. Yet adversarial legalism is a vigorous plant that has some attractive features. It is growing and probably will continue to spread in certain areas of European affairs. Thus if Europeans do not worry about it, adversarial legalism, with its unattractive as well as its attractive features, might blossom somewhat more widely than Europeans ultimately will appreciate.

\section{Adversarial Legalism}

Everywhere in the modern world, it seems, law is intruding more deeply into social and economic life. ${ }^{2}$ European legal scholars write of the increasing 'juridification' of labour relations, social welfare administration, and land use. ${ }^{3}$ Germany's litigation rate in tort cases approaches that of the United States. ${ }^{4}$

But more laws, regulations, and court cases are not the same thing as more adversarial legalism. The United States has a 'legal style' that remains distinctive. Its lawyers and judges are uniquely aggressive and creative-or, as critics would put it, presumptuous. In no other country are political decisions, such as the drawing of electoral district lines or the formulation of pollution control standards, so often re-examined and reversed by judges. In no other country do aggrieved citizens so often haul highway departments, prison wardens, and business corporations into court. Germans may file many tort suits, but nowhere is the tort law system so extravagantly costly, erratic, and fearsome as it is in the United States.

A growing number of excellent socio-legal studies carefully compare different national approaches to a particular social problem-such as compensating injured people, regulating nursing homes, or cleaning up toxic waste dumps. ${ }^{5}$ These comparisons generally point to seven distinctive characteristics of the American government process:

\section{1. more complex bodies of legal rules;}

2 Marc Galanter, 'Law Abounding: Legalization Around the North Atlantic', 55 Modern L Rev 1 (1992); Wolfgang Wiegand, 'The Reception of American Law in Europe', 39 Am $\mathcal{F}$ Comp Law 229 (1991); D. Trubek, Y. Dezelay, R Buchanan, \& J. David, 'Global Restructuring and the Law: The Internationalization of Legal Fields', Working Paper, Global Studies Research Program, University of Wisconsin, Madison, August 1993.

${ }^{3}$ See Gunther Teubner (ed) Furidification of Social Spheres (Berlin: Walter de Gruyter, 1987).

4 Basil Markesinis, 'Litigation-Mania in England, Germany, and the USA: Are We So Very Different?' 49 Cambridge Law foumal (1990) 233-76.

${ }_{5}$ Among the most perceptive cross-national comparisons are Joseph Badaraceo, Loading the Dice (1985) (vinyl chloride regulation in five countries); John Braithwaite, To Punish or Persuade: Enforcement of Coal Minc Safity (Albany: SUNX Press, 1985); P. Day \& R. Klein, 'The Regulation of Nursing Homes: A Comparative Perspective', 65 The Milbank Quartenly 303 (1987); R. Brickman, S. Jasanoff \& T. Ilgen, Controlling Chemicals: The Politics of Regulation in Europe and the United States (Ithaca: Cornell University Press 1985); Steven Kelman, Regulating America, Regulating Sweden: A Comparative Study of Occupational Safety and Health Policy (Cambridge: MIT Press, 1981); David Kirp, 'Professionalization as a Policy Choice: British Special Education in Comparative Perspective', 34 World Politics 137 (1982); John Langbein, 'The German Advantage in Civil Procedure' 52 Univ Chicago Laze' Review 823 (1985); Gary Schwartz, 'Product Liability and Medical Malpractice in Comparative Context', in P. Huber \& R. Litan (eds) The Liability Maze (Washington, DC: Brookings Inst, 1991); David Vogel, National Stylus of Regulation: Environmental Policy in Great Britain and the United States (Ithaca: Cornell University Press, 1986); Derek Bok, 'Reflections on the Distinctive Character of American Labor Laws' 84 Harvard Law Revicw 1461 (1971); Mary Ann Glendon, Abortion and Divore in Western Law (Cambridge: Harvard University Press, 1987). 
2. more formal, adversarial procedures for resolving political and scientific disputes;

3. more costly forms of legal contestation;

4. more punitive legal sanctions;

5. more frequent judicial intervention into political and administrative decision-making;

6. more political controversy about legal rules and institutions; and

7. more legal uncertainty and malleability.

Some of these legal propensities are captured in the summary concept 'adversarial legalism'. Table 1, which owes much to the work of Mirjan Damaska, ${ }^{7}$ helps distinguish adversarial legalism from other modes of policy-implementation and dispute resolution.

Table 1 Modes of Policy-Making and Dispute Resolution

\begin{tabular}{lll}
\hline & INFORMAL & FORMAL \\
\cline { 2 - 3 } HIERARCHICAL & $\begin{array}{l}\text { expert or political } \\
\text { judgment }\end{array}$ & bureaucratic legalism \\
\cline { 2 - 2 } PARTY-INFLUENCED & negotiation/mediation & adversarial legalism \\
\hline
\end{tabular}

Adversarial legalism differs first of all from informal modes of decision-making, such as mediation or expert judgment. But formal legal governance can range from hierarchical, as in Weberian bureaucratic legalism, to more participatory and party-influenced methods, that is, adversarial legalism. With respect to adjudication, for example, in continental European courts, bureaucraticallyorganized judges dominate fact-gathering, selection of expert witnesses, and trial procedures. ${ }^{8}$ In adversarial legalism, attorneys for the parties dominate those processes. Even compared to the British 'adversarial system' from which it descended, American adjudication is more party-influenced, less hierarchicallycontrolled. ${ }^{9}$ As Atiyah and Summers have shown, American judges are more diverse, political, autonomous, and adventuresome than British judges, and law in the United States is more open to novel legal and policy arguments put forth by parties and their lawyers. ${ }^{10}$

Adversarial legalism characterizes not merely American adjudication but also its entire approach to governance. For example, compared to European democracies, regulatory decision-making in the United States entails more legal formalities,

\footnotetext{
"I define adversarial legalism as a method of policy-making and dispute-resolution characterized by comparatively high degrees of: (a) formal legal contestation, and (b) litigant activism (or weak hierarchical control).

Firjan Damaska, The Faces of Fustice and State Authority (Yale University Press, 1986).

"John Langbein, 'The German Advantage in Civil Procedure', 52 U Chi L Rev 823 (1985).

S See Graham Hughes, 'English Criminal Justice: Is It Better Than Ours?’, 26 Arizona L Rev 507 (1984).

10 P.S. Atiyah \& R. Summers, Form and Substance in Anglo-American Law: A Comparative Study of Legal Reasoning, Ligal Theory, and Legal Institutions (Oxford: Clarendon Press, 1987).
} 
more interest group participation, and more aggressive judicial review. Hence, hierarchical authority in American agencies is comparatively weaker than in European regulatory bodies, where decisions are hammered out informally by technical experts and politicians, lawyers rarely participate, and agencies are rarely reversed by courts. ${ }^{11}$ Consider, too, national systems for compensating and providing medical care to accident victims. In the United States, a large role is played by the tort law system, which is legalistic, adversarial, and driven by litigant activism. Most European compensation systems, in contrast, emphasize hierarchically-organized benefit-payment bureaucracies or insurance schemes, in which most disputes are resolved by expert judgment or bureaucratic rules. ${ }^{12}$

Adversarial legalism, of course, does not pervade the American legal order uniformly or completely. ${ }^{13}$ Like all modern legal systems, it contains elements of all four kinds of decision-making on Table 1. Indeed, adversarial legalism is so cumbersome and costly, it virtually compels disputants to resolve most litigated disputes-civil, criminal and administrative-by informal negotiation. But adversarial legalism is far more common in the United States than elsewhere, and it more fully characterizes its legal structure.

\section{A. Benefits and Costs}

To judge from the American experience, adversarial legalism infuses a legal and political system with a unique kind of responsiveness. Adversarial legalism can be wholeheartedly admired for its openness to new ideas, for its ability to challenge governmental and corporate arbitrariness, for its empowerment of political, ethnic, and social minorities. Adversarial legalism is a remarkable technique for transforming new concerns, such as freedom from sexual harassment, into potent legal rights and remedies. It enabled new companies to crack open telecommunications and financial industry monopolies, ${ }^{14}$ and enabled parents of handicapped children to insist on better public education. ${ }^{15}$

But the legal machinery which can produce a Brown $\mathrm{v}$ Board of Education, and which can expose and punish corporate negligence, is difficult and expensive to operate. As an mode of everyday dispute resolution, adversarial legalism is woefully inefficient and erratic, and consequently it is often unjust. To use a

\footnotetext{
11 Badaracco, Loading The Dice, above n5; Brickman et al, Controlling Chemicals, above n 5; Vogel, National Styles of Regulation, above n 5; Teff, 'Drug Approval in England and the United States', 33 Amorican foumal of Comparative Law 567 (1985).

${ }^{12}$ Gary Schwart, 'Product Liability and Medical Malpractice in Comparative Context', above n 5.

${ }^{13}$ In some policy arenas, litigation and even the threat of it is infrequent. Many individuals, communities, subcultures, and industries disparage and avoid legal contestation. Carol Greenhouse, Praying for flustici: Faith, Order and Community in an American Town (Ithaca: Comell U Press 1986); Robert C. Ellickson, 'Of Coase and Cattle: Dispute Resolution Among Neighbors in Shasta County', 38 Stanfond L Rev 623 (1986); Stewart Macaulay, 'Non-Contractual Relations in Business: A Preliminary Study', $28 \mathrm{Am}$ Soc Rev 55 (1963); David Engel, "The Oven Bird's Song: Insiders, Outsiders, and Personal Injuries in An American Community', 18 Law and sociury Reziew, 551 (1984); Robert A. Kagan, 'The Routinization of Debt Collection', 18 Law E Soc'y Rev 323 (1984).

14 Stephen Vogel, Freer Markets, More Rules (Cornell University Press, 1995).

$15 \mathrm{R}$ Shep Melnick, 'Separation of Powers and the Strategy of Rights: The expansion of Special Education', in M. Landy and M. Levin (eds) The New Politics of Public Policy (1995).
} 
parochial sports metaphor, adversarial legalism, as it operates in the United States, is like a powerful baseball player who leads the league in magnificent home runs-but who often misses routine catches in the outfield, arrives late to the game, and demands such a large salary that many fans cannot afford to come to the ballpark. For example:

- Adversarial pretrial and adjudication processes in the United States are so slow, so costly, and so unpredictable that litigants, rich and poor, often are compelled to forego legally meritorious claims and defences-more often, it seems logical to infer, these in European systems, including the British, where pre-trial discovery and litigation are less adversarial, less expensive, and more predictable. ${ }^{16}$

- In 1992, New York City spent more money on liability claims than on the operation of all its parks and libraries, ${ }^{17}$ and the liability insurance costs of American obstetricians and chemical manufacturers dwarf those of their European counterparts. ${ }^{18}$

- The prospect of challenge in court often paralyses government action, as administrators order up more scientific research, economic analyses, and legal opinions, hoping that their regulations or licensing decisions can be made legally bulletproof. ${ }^{19}$ Court-prescribed procedures for involuntary commitment of mentally ill individuals have become so demanding and complex that, according to some observers, police and hospital personnel often refrain from initiating the commitment process even when they feel it is fully warranted. ${ }^{20}$

- Because adversarial litigation is so costly, lawsuits can be used as purely strategic weapons-not to remedy perceived injustices but to impose litigation costs on and extort concessions from the opposing party. Examples are said to be abundant in situations involving resistance to corporate hostile takeovers, ${ }^{21}$ trade secret litigation against former employees who leave to start a new company, ${ }^{22}$ lawsuits designed to intimidate homeowners who organize opposition

\footnotetext{
1t. In lawsuits seeking damages for personal injuries, lawyers for both sides absorb an astonishing 40 or 50 per cent of the sums that liability insurers expend on litigated claims. James S. Kakalik \& Nicholas M. Pace (1986) Costs and Compinsation Paid in Tort Litigation, (Santa Monica, CA: Institute for Civil Justice, RAND Corporation); James S. Kakalik, et al (1983) Costs of Asbestos Litigation (Santa Monica, CA: Institute for Civil Justice, RAND Corporation; Institute for Civil Justice, 1990: 49-54). See generally, Kenneth S. Abraham \& Lance Liebman (1993) "Private Insurance, Social Insurance, and Tort Reform: Toward a New vision of Compensation for Illness and Injury', 93 Columbia L Rev 75-118; Paul C. Weiler (1991) Medical Malpractice on Trial (Cambridge: Harvard Univerity Pruss). On the grcater predictability of litigation in Great Britain, see P.S. Atyah \& R. Summers, Form and Substance in Anglo-Amcrican Law (Oxford: Clarendon Press, 1987) 161-76, 193-208.

${ }_{13}$ Mycson, 'Soaring Liability Payments Burden New York's Budger', New York Times, 29 June 1992, A15.

1\% Donald Dewees, Michael Trebilcock, and Peter Coyte, (1991) 'The Medical Malpractice Crisis: A Comparative Empirical Perspective', 54 Law and Contcmporary Problems 217-51. Franklin Nutter \& Keith Bateman (1989) The Unutd Status Ton System in the Era of the Global Economy (Schaumberg, ILL: Alliance of American Insurers).

"' John Afundeloff, (1987) The Dilemma of Rulemaking for Toxic Substancos (Cambridge, MLA: MIT Press), John Dwyer, (1990) 'The Pathology of Symbolic Legislation', Ecology Law Quancrly 17: [1990]: 233-316; Jerry L. Mashaw, \& Daniel Harfst (1987) 'Regulation and Legal Culture: The Case of Motor Vehicle Safety', Yale fournal an Regularion 4: 257-316.

2" Robert Ellickson, (1990) 'The Homelessness Muddle' The Public Interest 99: 45-60.

2 Herburt Wachtell, 'Special Tender Offer Litigation Tactics', 32 Bus Law 1433 (1977).

22 See Alexander Silverman, 'Symposium Report: Intellectual Property Law and the Venture Capital Process', 5 High Tech LF 157 (1990)
} 
to large scale developments, ${ }^{23}$ and lawsuits that contest the wills of the very wealthy. ${ }^{24}$

Finally, by making legal processes costly, complex, uncertain, and threatening, adversarial legalism seems to alienate citizens from the law itself. A national business and professional élite that trades jokes demeaning lawyers and legal processes can be mobilized to support mean-spirited legal reforms that would not only curtail adversarial legalism's excesses but would also destroy its virtues, diminishing rights to litigate without providing any alternative mechanisms to ensure accountability, compensation, or justice.

\section{Change in National Legal Systems}

Compared to the United States, European judiciaries are selected in a much less political manner, and judges traditionally have a much more restricted policymaking role. Whereas American legal education and scholarship emphasize legal creativity and policy-arguments, European legal education and scholarship emphasize black letter law, and logical coherence. Whereas American lawyers' ethics encourage zealous advocacy and legal entrepreneurship, European legal ethics encourage a more reserved from of advocacy, including some deference to larger societal interests. Hence one might believe that European political and legal traditions would be distinctly inhospitable to any seeds of adversarial legalism that might blow across the Atlantic.

That belief, however, assumes that legal cultures and practices are rather stable. A competing perspective would suggest that legal cultures and practices can be changed by broader economic forces, or by shifts in political power and political structures. Only a generation ago, the decisions of American school administrators rarely were challenged in court. Both criminal and civil trials were far shorter. Between 1960 and 1987, expenditures on lawyers in the United States grew sixfold, almost tripling the share of GNP consumed by legal services. ${ }^{25}$ Between 1960 and 1980, civil rights cases against the Government in federal courts alone increased from 280 a year to about $27,000,{ }^{26}$ federal court appellate cases involving constitutional issues increased seven-fold, ${ }^{27}$ and legal complaints against unfair

\footnotetext{
${ }^{23}$ Penelope Canan \& George Pring, 'Studying Strategic Lawsuits Against Public Participation', 22 Law E' Society Review 385 (1988)

${ }^{24}$ John Langbein, 'Will Contests' (Review of David Margolick, Undue Influence: The Epic Battle for the Johnson E' fohnson Fortune) 103 Yale Lf 2039 (1994)

${ }_{25}$ American expenditures on legal services increased from $\$ 9$ billion annually in 1960 to $\$ 54$ billion in 1987 (in constant 1983 dollars), R. Sander \& E.D. Williams, Why Are There So Many Lawyers? Perspectives on a Turbulent Market', 14 Law $\mathcal{F}$ ' Social Inquiry 431, 434-5 (1989)

${ }^{26}$ Peter Schuck, Suing Government: Citizen Remedies for Official Wrongs, 199-202 (New Haven, Yale University Press, 1983).

${ }_{27}$ Robert A. Kagan, (1987) 'Constitutional Litigation in the United States', in R. Rogowski \& T. Gawron (eds) Constitutional Courts in Comparison (Gummersbach, West Germany: Theodor Huess Academie).
} 
labour practices almost quadrupled. ${ }^{28}$ Medical malpractice suits, rare in 1960, reached 4.3 per 100 physicians in 1970 and 18.3 per 100 in $1986 .{ }^{29}$ In 1961 , American administrative law was rather dull; the Government almost always won appeals to court and hence lawsuits challenging administrative decisions were rare. By the early $1980 \mathrm{~s}$, however, more than 80 per cent of the Environmental Protection Agency's major new regulations were suspended (at least temporarily) by court challenges, ${ }^{30}$ as was virtually every US Forest Service management plan, ${ }^{31}$ new motor vehicle safety regulation, ${ }^{32}$ Department of Interior lease for offshore petroleum exploration, ${ }^{33}$ and seaport dredging plan. ${ }^{34}$

What caused this intensification of adversarial legalism in the United States? And do the same causal factors have parallels in Western Europe? The discussion can be divided into two segments: first, the growth of adversarial legalism in economic life, second, in public law.

\section{Adversarial Legalism in the Economic Sector}

As far as I know, Europe has very few specimens of the table-pounding Wall Street lawyers described in James Stewart's book The Partners. In corporate takeover struggles, law firm partners, as Stewart describes it, deploy teams of indefatigable young attorneys like squadrons of fighter planes, bombarding their corporate adversaries with pre-emptive lawsuits, demands for truckloads of documents, and pre-trial motions, trying to spend and to stall their adversaries into submission..$^{35}$ At a more mundane level, I have interviewed ocean shipping firm officials who assert that although the substantive law in New York and Rotterdam is the same, they prefer to resolve cargo damage disputes in Rotterdam, because Dutch lawyers are far less expensive, adversarial and legalistic than their New York counterparts; because adjudication in the Dutch courts is faster and more reliably professional; and because overall, negotiations in The Netherlands are 'more human'. ${ }^{36}$

How can we explain these differences? We can start with economic structure. American capitalism has always been more decentralized and competitive than most European market-oriented economies. American markets less often are

\footnotetext{
${ }^{25}$ Unfair labour practice claims grew from about 13,000 annually in 1960 to about 45,000 in 1980 , even as the events that might accasion such complaints (representation elections, collective bargaining negotiations, work stoppages) remained at a steady level. Robert Flanagan, Labor Relations and The Litigation Explosion (Brookings, 1987) at 33.

${ }^{9}$ Lois Quam et al (1987) 'Medical Malpractice in Perspective’, British Medical foumal 294: 1529-31; $1597-600$. See also Donald Dewees et al above $\mathrm{n} 18$.

34. Laurence Suskind \& Gerald McMahon, 'The Theory and Practice of Negotiated Rulemaking', 3 Yale $\mathcal{F}$ on Rrgulation, 133, 134 (1985)

31 'The Forest Service: Time for a Little Perestroika', The Economist, 10 March 1990, 28.

${ }_{32}^{3}$ Jerry Mashaw \& Daniel Harfst, The Struggle for Auto Safety, (Cambridge, MA: Harvard Univ Press, 1990).

${ }^{33}$ Charles Lester, "The Search for Dialogue in The Administrative State: The Politics, Policy, and Law of Offshore Oil Development', PhD Dissertation, University of California, Berkeley, 1991.

${ }^{14}$ Robert A. Kagan, "The Dredging Dilemma: Economic Development and Environment Protection in Oakland Harbor', Coastal Mranagement 19 (1991). 313-41.

${ }^{35}$ James Stewart, The Partners: Inside America's Most Powerful Law Fïms (NY: Simon \& Schuster, 1983).

36 Robert A. Kagan, 'What Makes Uncle Sammy Sue?' Law and Society Review, 21:718-42 (1988).
} 
dominated by cartels, huge banks, or nationalized companies. Compared to most European economies, therefore, there have been fewer institutions that can informally contain conflict between businesses, punish misbehaviour, or forestall insolvency. Regulation of commercial relations, accordingly, always has been left more fully to the realms of contract law, private litigation, legalistic regulation, and lawyering. ${ }^{37}$

Nevertheless, until recently, litigation among American business firms was not very common. Thirty years ago, Stewart Macaulay found that midwestern businessmen embroiled in disputes were very reluctant to invoke contractual terms and insist on legal compliance. They were more reluctant still to resort to litigation. ${ }^{38}$ But by the 1970 s and 1980 s, lawsuits among business firms had become the most rapidly growing category of litigation. ${ }^{39}$ Large law offices serving corporate clients swelled to enormous proportions, expanding far more rapidly than the volume of transactions..$^{40}$ Corporations had to take out insurance policies to protect their officers and directors from personal legal liability; the rates they had to pay for such insurance skyrocketed. ${ }^{41}$

\section{A. International Economic Competition}

The primary source of this newfound business litigiousness, I believe, was intensified international economic competition and integration. Falling trade barriers, huge improvements in international cargo transportation, ${ }^{42}$ increased mobility of capital, and sharper worldwide competition all tended to erode longstanding deterrents to litigation.

A basic theorem in socio-legal studies is Donald Black's proposition that resort to law increases in accordance with the social distance between parties, while resort to law is suppressed when parties are enmeshed in continuing relationships. ${ }^{43}$ Divorcing spouses can battle in court; spouses unwilling to divorce only argue.

${ }^{37}$ As Martin Shapiro observes: 'America may use so many lawyers in business and governmental dealings less because we have a special affection for lawyers, than because economic and political power has been widely dispersed among scattered, disparate elites who cannot get together at their club or countryhouse, because they do not have one, and who would find that they had little in common upon which to build mutual trust cven if they did have a meeting place. Where there are no gentlemen, there have to be contracts, rather than gentlemen's agreements'. 'The Globalization of Law', 1 Indiana f of Global Legal Studies 37, 42 (1993).

Stewart Macaulay, "Non-Contractual Relations in Business: A Preliminary Study', American Sociological Revicu" 28:55 (1963).

${ }^{39}$ In federal courts, contract cases grew eight-fold, from about 4000 in 1960 to 32,000 in 1986. Marc Galanter, 'The Life and Times of the Big Six; or, The Federal Courts Since the Good Old Days', 1988 Wisconsin L Rev 921, 943. See also William Nelson, 'Contract Litigation and the Elite Bar in New York City, 1960-1980', 39 Emory Law Review 413 (1990); T. Dungworth, M. Galanter and J. Rogers, 'Corporations in Court: Recent Trends in American Business Litigation', Paper delivered at Annual Meeting of Law and Society Association, Berkeley, CA 1990.

40 Mare Galanter \& Thomas Palay, Toumament of Lawyen: The Transformations of The Big Law Fim (Chicago: University of Chicago Press, 1992).

${ }_{41}$ Roberta Romano, 'Corporate Governance in the Aftermath of the Insurance Crisis', in Peter E. Schuck (ed) Tort Law and the Public Interest: competition, Innovation and Consumer Welfare, (NY: W.W. Norton 1991) 150-75. According to one survey, average damage claims in shareholders' lawsuits against officers and directors increased from $\$ 550,000$ in 1976 to $\$ 4.27$ million in 1992 . The median amount in legal defence costs in cases that were settled in 1992 was $\$ 250,000$.

${ }_{22}$ Robert A. Kagan, Pattems of Port Development (Berkeley, CA: Institute of Transportation Studies, 1991).

43 Donald Black, The Behavior of Law (NY: Academic Press, 1976). 
In a more competitive global economy, American businesses found themselves dealing with strangers-companies with whom they had no long-standing mutual expectations of forbearance and reciprocity. At the same time, as globalization provided access to alternative business partners, companies became less reluctant to divorce their current partner, and hence less reluctant to sue for damages. It seems logical to expect globalization gradually to affect European corporations in the same way.

In the globalizing economy, competitive pressures induced many American corporations to separate financial management from operations, to take tougher stands against labour unions, and to 'contract out' a wider array of functions to outsiders. These steps too led to more distanced relationships, and more litigation. ${ }^{44}$ European corporations also are pressured by international competition to diversify and to become 'leaner and meaner', as the saying goes-thereby inviting more short-term and presumably more legalistic relationships.

In the United States, dynamic changes in corporate finance also stimulated adversarial legalism. Waves of mergers and bidding wars for corporate control led to rapid shifts in corporate management and more high-stakes, risky transactions between strangers. More dynamic credit markets made financing arrangements more complicated, engaging larger numbers of players. With more high-stakes relationships among strangers came demands for legal protections against opportunism. American legislatures and courts formulated new regulations and private rights of action to punish financial deception, insider trading, bankruptcy abuse, risky forms of trading, and unjust employee dismissals. There were more lawsuits against corporate managers, more lawsuits between debtors and creditors, more strategic use of litigation to intimidate and extort. ${ }^{45}$ Corporations invested in more detailed, costly legal documents, designed to fend off those legal risks.

In Europe, too, despite a history in which corporate finance has been dominated by large banks and interlocking corporate groups, the trend has been toward liberalization of financial markets and toward more fluid, public, and international modes of corporate finance. ${ }^{46}$ European corporate managers now more often are strangers to their creditors and stockholders, and vice versa. Thus we begin to see more European legal techniques that mimic methods pioneered in the US-legalistic financial regulation, ${ }^{47}$ commercial litigation, and detailed, defensively-written contracts. ${ }^{48}$ Swiss law professor Wolfgang Wiegand writes, 'In

\footnotetext{
44 Martin Shapiro, 'The Globalization of Law', at 41. William Nelson, 'Contract Litigation and the Elite Bar', above $\mathrm{n} 39$.

${ }^{15}$ For studies demonstrating the extortative character of many shareholders securities class actions, see Janet Cooper Alexander, 'Do the Merits Really Matter? A Study of Settlements in Securities Class Actions', 43 Stanford L Rev 497 (1991); Roberta Romano, 'The Shareholder Suit: Litigation Without Foundation?' 7 f Law, Economics and Onganizations 55 (1991).

${ }^{t 5}$ See John C. Coffee, Jr, 'Liquidity Versus Control: The Institutional Investor as Corporate Monitor', 91 Columbia Law' Rev 1277 (1991); 'Those German Banks and Their Industrial Treasures', The Economish, 21 January 1995 , at 71 .

${ }^{47}$ See Harvey Pitt \& David Hardison 'Games Without Frontiers: Trends in International Response to Insider Trading', 55 Law \& Contemporary Problems, 199

${ }^{44}$ Martin Shapiro, 'The Globalization of Law', at 41.
} 
the seventies a merger of two Swiss firms with more than 1 billion dollars turnover per year was done in a contract of less than ten pages. Nowadays I am sure it would be 100 pages or more'. ${ }^{49}$

\section{B. Competition in Legal Services}

The general counsel of an American computer manufacturer recently told me about a contractual dispute that led to litigation in the British courts. The wellrecommended English barristers and solicitors he retained disappointed him very badly. 'They don't know how to litigate!' he claimed. The American corporate counsel explained that he was accustomed to American law firms that quickly assemble a team of attorneys and work all weekend to answer a question or prepare a document. Instead of taking charge in similar fashion, he said, the British lawyers 'just want to sit back and answer legal questions that might be posed to them'. He wanted warrior litigators, not gentlemen legal advisors. In subsequent contracts with British companies, the American lawyer now insists that disputes, even if to be decided under British law, must be decided in Paris under the rules of the International Arbitration Association. In that forum, the computer company can use its own brand of aggressive litigators.

Now imagine the next scene, in which a British business firm is locked in international arbitration with the same American computer company-and its team of legal bulldogs. The British company presumably would be well advised to hire an equally fierce team, thereby accelerating the litigation arms race. That is exactly what emerges from a study by Bryant Garth and Yves Dezelay, who find that American lawyers now play a larger role in international arbitration, and are pushing arbitration toward a more adversarial style. ${ }^{50}$ Furthermore, to deal with their legally aggressive American adversaries, European lawyers are forging partnerships with American firms and hiring associates who have had American training. In consequence, Wolfgang Wiegand argues, 'the style of legal arguing and the handling of the litigation is increasingly influenced by American models, ${ }^{51}$ nudging domestic European litigation in a more adversarial direction.

\section{Privatization and Deregulation}

International competition has also fueled a worldwide trend toward privatization and deregulation. This, too, by reducing hierarchical controls, stimulates adversarial legalism. In the United States, private enterprises discharge many social functions that in Europe have been conducted by governmental entities-for example, broadcasting, telecommunications, rail and air transportation, hospitals,

\footnotetext{
49 Wolfgang Wiegand, 'Americanization of Law-Reception or Convergence', in Lawrence Friedman \& Harry Scheiber (eds) Legal Culture and the Legal Profession (Westport, CT: Westwood Press, 1996)

${ }^{50}$ B. Garth \& Y. Dezelay, 'Merchants of Law as Moral Entrepreneurs: Constructing International Justice from the Competition for Transnational Business Disputes', 29 Law and Society Revierw, 27-64 (1995) See also Wolfgang Wiegand, 'Americanization of Law' (intemational arbitration increasingly leans toward the American model of dispute resolution, particularly its endorsement of aggressive, lawyer-conducted pre-trial discovery).

51 Ibid.
} 
and worker injury insurance. Moreover, viewed comparatively, American banking is far more decentralized, less closely tied to the State. The US relies more heavily on private pension funds and health insurance. The 'privatized', fragmented American economy has meant more social control by means of contract, private litigation, and legalistic forms of governmental regulation. ${ }^{52}$

From that perspective, the rush of many European nations to substitute competition for governmental monopolies seems likely to generate more legalistic forms of regulation, and more litigation. Stephen Vogel's cross-national analysis of privatization and deregulation in financial services, telecommunications, public utilities, and transportation is entitled 'Freer Markets, More Rules'. ${ }^{53}$ With liberalization, he finds, control by law replaces informal hierarchical controls. ${ }^{54}$ In the United Kingdom, for example, privatization of water and electric supply bodies led to a new, more legalistic regulatory regime, and this has made Britain 'susceptible to the American disease: more lawyers and ever more complex and detailed rules'. ${ }^{55}$

Adversarial legalism also is spread by national competition for economic advantage. Deregulation of trading commissions by the New York Stock Exchange helped convince British authorities to deregulate, so that London would not lose stock trading activity to New York. The 'Big Bang' of 1986, in turn, was followed by a new, more legalistic regulatory regime in which courts more often are called upon to resolve disputes. ${ }^{56}$ In a variety of other policy areas, American multinationals, accustomed to transparent, legalistic regulation, push other Governments to adopt similar standards, and the American Government often lends its considerable weight to that demand. ${ }^{57}$ International economic pressures seem to be impelling European welfare states to consider adoption of privately-provided insurance schemes for social and medical benefits, retirement funds, and so on. To the extent such steps toward privatization occur, then one would expect, as in the United States, more external legal regulation of the relevant insurance companies, and more litigation over eligibility disputes.

\section{Adversarial Legalism and Public Law}

In the United States, adversarial legalism in the public sector has been fueled by the confluence of two political factors:

\footnotetext{
52 David Vogel, National Styles of Regulation. Socio-legal studies repeatedly indicate that the more fragmented and competitive the regulated industry, the more legalistic regulation and enforcement tends to be. Robert Kagan, 'Regulatory Enforcement', in D. Rosenbloom \& R. Schwartz, Handbook of Administrative law and Regulation (NY: Marcel Dekker, 1994).

${ }_{53}$ S. Vogel, Frer Markets, Mone Rules: Regulatory Reform in the Advanced Industrial Countries (Cornell University Press, 1996).

54 Vogel notes that some nations, such as France, Japan and Germany, while liberalizing and privatizing, have tended not to not adopt American style arms-length adversarial legalism as a mode of re-regulation or control. But there are powerful tendencies in that direction.

55 Id at 120 .

56 Michael Moran, The Politics of the Financial Services Revolution: The USA, UK and Japan (NY: St. Martins Press, 1991).

57 Id at 17.
} 
1. a political culture that came to demand increasingly comprehensive governmental protections from harm, injustice, and environmental dangers-and hence a more powerful, activist central government;

2. governmental structures based on mistrust of concentrated power, and hence that fragment governmental authority, and seek to control it by lawsuits and judicial review.

\section{A. Political Mistrust of Central Government Power}

Beginning in the mid-1960s, American political movements-in civil rights, environmental protection, consumer protection, the War on Poverty-demanded more aggressive legislation by the national Government, pre-empting weaker state and local laws. To implement the new laws, the reformers demanded new, powerful national regulatory agencies. But they also mistrusted government, fearing that the national agencies would be underfunded and inept, or would be captured by the regulated.

The reformers' remedy was to demand legal rights that empowered advocacy groups to influence governmental policy. The new national statutes, accordingly, included deadlines for administrative action, detailed restrictions on administrative discretion, and private rights to ask courts to ensure agency compliance with those legal mandates. The laws also required federal agencies to base their actions on policy analyses and scientific findings that could be scrutinized and challenged by advocacy groups and by reviewing courts. ${ }^{58}$ The regulated business community and political conservatives, too, distrusted the new, more powerful national agencies. They demanded legislative provisions that empowered business to demand judicial scrutiny of regulatory rationality. Consequently, adversarial legalism-that is, formal legal contestation, initiated by contending private interests-became a dominant accountability mechanism for new, more powerful, but more distant and distrusted governmental bodies.

Similarly, recent trends in European administrative law, Martin Shapiro contends, reflect growing popular distrust of bureaucratic discretion based on claimed expertise. $^{59}$

No one ... [Shapiro observes] proposes doing away with bureaucratic government. ... Instead [they seek] increased transparency of, and increased public participation in, bureaucratic decisionmaking. ${ }^{60}$

In Europe as in the United States, assertive non-governmental organizations demand access to courts in order to influence the administrative process. Jefferey Sellers systematically identified significant land development disputes that arose in the 1970 s and 1980 s in three comparable metropolitan areas-Freiburg,

${ }^{58}$ Eugene Bardach \& Robert Kagan, Going By The Book: The Problem of Regulatory Unneasonableness (Philadelphia: Temple Univ. Press, 1982) ch 2; Martin Shapiro, Who Guards the Guandians? Fudicial Control of Administration (Athens: University of Georgia Press, 1988); Michael McCann, Taking Reform Seriously: Public Intenst Libcralism (Ithaca, NY: Cornell University Press, 1986).

${ }_{59}$ Shapiro, 'The Globalization of Law' at 45.

60 Id at 46. 
Germany; Montpellier, France; and New Haven, Connecticut. In the New Haven area, 50 per cent of the disputed administrative land use decisions were challenged in court. But surprisingly, land use disputes resulted in litigation almost as often in Montpellier (44 per cent of disputes) and in Freiburg ( 42 per cent)-although those appeals went to administrative courts rather than to courts of general jurisdiction. Moreover, in both Germany and France, opponents of development projects who challenged administrative decisions in court were just as likely to win as were American project opponents. ${ }^{61}$

In addition, just as the expansion of a distant central government in Washington, DC triggered adversarial legalism in the United States, Shapiro notes:

The strengthening of the European Community has increasingly centralized and distanced government regulatory power in Brussels, and as a result there is increasing European interest in increasing the transparency of, and public participation in, the decisions of the new Eurocrats. ${ }^{62}$

Legal rules and procedures are the logical tools for guaranteeing transparency, equal participation, and fairness. Hence European Union regulations generally are described as more legalistic than Member State regulations, and, as Shapiro observes, "both as providers of legal services and as lobbyists, lawyers are already playing a larger role in Community regulatory affairs than they traditionally have played in the national regulations undertaken by the member states'. ${ }^{63}$

\section{B. Ambitious Regulation in a Federal System}

In the United States, the effort to implement ambitious nationwide laws through a decentralized political structure has been another engine of adversarial legalism. In the decentralized American polity, national legislation forbidding discrimination, environmental degradation, and other harms necessarily delegated a great deal of first-order implementation to state and local governmental officials. But how could reformers be sure that those far-flung local Governments would enforce the ambitious national norms? The answer was adversarial legalism. Congress gave citizens and advocacy groups legal rights and financial incentives to appoint themselves 'private attorneys' general'-to bring private lawsuits against state and local governments for half-hearted implementation of national laws, and in some cases to sue businesses directly for regulatory violations.

\footnotetext{
1.1 Jeffery M. Sellers, (1995) 'Litigation as a Local Political Resource: Courts in Controversies Over Land Use in France, Germany and the United States', Law and Society Review 29:475-516. American developers and their opponents, Sellers found, were far more likely to use lawyers, even in cases that did not result in litigation. And American dezelopers (as opposed to project resisters) were far more likely than their French and German counterparts to challenge administrative land use decisions in court (often successfully); only opponents-primarily ntighbourhood and environmental organizations-litigated in Europe.

"Shapiro, 'The Globalization of Law' at 56.

63 Id at 57-8. Similarly, in Great Britain, according to Jonathan Levitsky, 'The Europeanization of the British Legal Style', $42 \mathrm{Am}$ f Comp L 347, 375 (1994) 'As a result of Community membership, British courts [gradually] are adopting European administrative law principles and applying them in purely domestic cases', thereby expanding the opportunities of advocacy groups and interest groups to challenge governmental policy in court.
} 
Similarly, the Government of the European Union is called upon to promulgate community-wide norms. But it does not have its own local-level enforcement bureaucracy. It must rely on Member-States to enact implementing legislation and to enforce those norms. Logically, then, one would expect proponents of Europe-wide norms, like American reformers, to seek legal rules that empower private advocacy organizations to bring lawsuits against Member-State Governments which are not administering EU directives enthusiastically. ${ }^{64}$ One would expect regulated businesses in 'high-compliance' member-states to push for expanded rights to take direct legal action against noncomplying Governments and competitors. Conversely, opponents of expansions of EU regulatory authority, like American opponents of federal regulation, may turn to adversarial legalism, using Member-State courts to contest or limit EU directives-as encouraged by the German Constitutional Court's recent Maastricht decision. ${ }^{65}$

\section{Governmental Deadlock and Fudicial Activism}

Adversarial legalism, I have been suggesting, flows from strong political demands for governmental action, combined with governmental weakness. When central Governments cannot deploy bureaucrats, they can respond to political demands by allowing citizens to deploy lawyers and lawsuits. Similarly, when central Governments are not dominated by strong, cohesive political parties (or coalitions of parties) they often cannot respond quickly and coherently to political demands. The resulting deadlock invites litigation and judicial activism.

In the United States, for example, the congressionally dominant party, the Democrats, for many years was hopelessly divided. Southern Democrats repeatedly blocked congressional action on racial issues and civil rights. Frustrated reformers, therefore, took to the courts; in 1954, the Supreme Court, in one bold swipe, declared racially segregated schools unconstitutional. The idea began to flourish in law schools and in the judicial community that if legislatures failed to act against grave social injustice, then it was incumbent on the Courts to fill the breach. In the 1960s, federal judges, re-reading the Constitution, began to issue reform orders to oppressive southern state prisons and to retrograde state mental institutions. Appalled by reports of abusive police practices, the Supreme Court, again re-interpreting the Constitution, prescribed nationwide rules of criminal procedure. In Gideon v Wainwright (1963), the Court held that the Constitution required states to give indigent defendants free defence lawyers. Thus, the Court literally mandated a new adversarial enforcement mechanism for its new nationwide criminal procedure norms.

In these and many other examples, political weakness or deadlock at the governmental centre encouraged judicial activism, which led in turn to a litigant-activated, legalistic mode of elaborating and implementing the new

\footnotetext{
64 Thus in the Francovich case, the European Court of Justice seemed to encourage private claims against Member States that failed to execute a Council Directive, Common Market Review 29 (1992) 557-84.

${ }_{65}$ See generally Steve J. Boom, 'The European Union after the Maastricht Decision: Will Germany be the 'Virginia of Europe'? 43 Af Comp Law 177 (1995).
} 
judicially-declared norms. The same dynamic, in muted form, seems to have affected the European Court of Justice and the Court of Human Rights. These Courts are staffed by judges drawn from the restrained, apolitical judiciaries of their respective national legal systems; they came to the European Courts with judicial philosophies far removed from the instrumental, social-engineering vision of law that infuses American legal education and the American judiciary. But confronted by a European Community Government often deadlocked by the unanimity requirement, the European Court of Justice in the 1960 s and 1970s became the most dynamic policy making institution in the Community. ${ }^{66}$ Through expansive interpretation of the Treaty of Rome, the Court of Justice paved the way for community-wide environmental regulation, ${ }^{67}$ ruled that EEC law was enforceable by citizens in national courts, ${ }^{68}$ and forged the ground rules for reconciling national product regulations with free trade. ${ }^{69}$ Similarly, the European Court of Human Rights developed 'Community human rights principles' against which domestic law can be measured by Member-State judiciaries. ${ }^{70}$

EU directives often are the product of political compromise and are highly instrumental in character-quite different from the formally rationalized codes of civil law countries, more like the painfully stitched-together legislation that emerges from the American Congress. Thus EU law seems to demand a different mode of judicial interpretation, even as it is incorporated into domestic law. Interpreting policy-oriented EU law, the European judicial style, one scholar argues, seems 'slowly, tentatively, to be moving toward an American [judicial style] -in which the judges rely on arguments from principle ... at the expense of formal rules'. And some scholars suggest that little by little, the judicial philosophy of American courts-that judges must act when the legislature has failed to address a pressing problem-is gaining ground in Europe. ${ }^{71}$

\section{Sources of Resistance}

To summarize, I have pointed to deep economic and political trends which have intensified adversarial legalism in the United States-international competitive pressures; more commercial and financial relations with strangers; privatization and its corollary, legalistic re-regulation; increasing political demands for transparency and participation in government, enforced through administrative law; the challenge of implementing ambitious central Government regulations through state and local Governments (a difficulty addressed through private legal rights

\footnotetext{
66 Shapiro, 'The Globalization of Law' at 58. See also Joseph Weiler, 'The Transformation of Europe', 100 Yale Lf 2403 (1991).

67 See Dirk Vandermeersch, 'The Single European Act and the Environmental Policy of the EEC', 12 Eurpean Law Review 407 (1987).

ok Id at 58.

"'. David Vogel, Trading Up: Consumer and Environmental Regulation in a Global Economy (Cambridge: Harvard University Press, 1995).

${ }_{741}$ Jonathan Levitsky, 'The Europeanization of the British Legal Style' $42 \mathrm{Am} \mathcal{F}$ Comp L 347, 352 (1994)

71 See Hjalte Rasmussen, On Law and Poliyy in the Eumpean Court of fustice (Boston: Nijhoff, 1986) 62-4; Mauro Cappelletti, 'Is European Court of Justice 'Running Wild'? European Law Review (Feb 1987) 3-5; Levitsky, at 380 .
} 
and private litigation); and finally, governmental political weakness, combined with intense political demands for governmental action, which encourages judicial activism.

All of these factors, we have seen, are affecting European economic and political systems. Traditional ways of governance and of doing legal business, many Europeans feel, are being eroded by larger economic and political forcesglobal economic competition, economic liberalism, the weakening of the welfare state, the declining position of labour unions and the rise of more distant, more legalistic transnational government. And in consequence, there is scattered evidence that some features of adversarial legalism are on the rise in Europe.

On the other hand, while the forces that have increased adversarial legalism in the United States affect European nations, they encounter there a very different and more resistant set of legal traditions and governmental structures. To shift metaphors, some seeds of adversarial legalism are taking root in some patches of Europe. But they encounter a soil that is far less welcoming to adversarial legalism than is American political and legal culture, and hence they are not likely to spread nearly as luxuriantly as they do in the United States.

The first source of resistance is the tenacity of European national legal cultures. Confronted with a proposed institutional transplant from a foreign legal system, most European judges and law professors attack it like antibodies swarming about a dangerous virus. In legal systems in which it takes months to decide such issues as whether solicitors may wear wigs in court, and then decide it would represent too sharp a break from tradition, one can rest assured that proposals evocative of adversarial legalism will receive extensive critical scrutiny.

Adversarial legalism, with its emphasis on responsiveness rather than on legal coherence and its inherent scepticism towards legal authority, is antithetical to European assumptions about law, legal ordering, and adjudication. ${ }^{22}$ European legal elites, it seems reasonably safe to predict, generally will resist core supports for American-style adversarial legalism—such as politically-selected judiciaries; wide-ranging judicial powers to mandate and monitor institutional reforms; and official encouragement of civil litigation to enforce public law. ${ }^{73}$ European legal and political élites are not likely to institute civil jury systems and openended rules for calculating money damages-and hence they will not experience unpredictable multi-billion dollar verdicts like those handed down by juries following the Exxon Valdez petroleum spill and Pennzoil's suit against Texaco after having been outduelled in a race to purchase Getty Oil. ${ }^{74}$ Similarly, although European judges may be becoming more policy-oriented, they still are profoundly uncomfortable with the unbridled instrumentalism of many American judges. The European Court of Justice, observers now claim, has retreated to a path of

\footnotetext{
${ }^{72}$ Mirjam Damaska, Faces of Fusrice and State Authority (1986) above n 7; Kagan, 'What Makes Uncle Sammy Sue?' above $n 36$.

${ }^{73}$ See Josephine Steiner, 'How to Make the Action Suit the Case: Domestic Remedies for Breach of EEC Law', Eumpean Law Review 0102.

${ }_{74}$ See Roger Baron \& Ronald Baron, 'The Pennzoil-Texaco Dispute: An Independent Analysis', 38 Baylor $L$ Rev 253-97 (1986).
} 
'judicial minimalism'. ${ }^{75}$ It would be rash to predict that the Court of Justice or the European Court of Human Rights soon will make decisions as sweeping, as legally controversial, and as politically transformative as the US Supreme Court decisions that established womens' rights to abortion, that banned prayer in public schools, and that required state governments to redraw electoral district lines.

A second and equally important source of resistance is structural: the tenacity of the bureaucratically-administered European nation-state. It may be true that in Europe, as in the United States, mistrust of government is producing demands for participation, transparency, and stronger administrative law. And it may also be true that the rise of a distant supranational government in Brussels, like the growth of central government in the United States, encourages adversarial legalism as a technique of ensuring local implementation of centrally formulated regulations. But both trends have been, and are likely to continue to be, but a pale shadow of their American counterparts, primarily because of the continued vitality and density of European nation states.

In relation to its Member States and their citizens, the European Union is not nearly as powerful as the United States federal government, which has its own nationwide system of local prosecutors, tax collectors, regulatory agencies, and courts. In the United States, the federal government enacts law that explicitly empowers citizens to bring suit, in federal courts, against state and local government bodies or business corporations for violation of federal law, as well as against the agencies of the federal government. The European Union does not have its own local court system. In implementing policy, it must work through Member States-which retain discretion in crafting their own legal means of implementing EEC directives. And European Member States, compared to American governments, national or state, are structurally more resistant to the advocates of adversarial legalism. The sources of resistance are imbedded, like an animal's skeleton, in their political institutions.

For example, in European national bureaucracies, selective recruitment, hierarchical control, and political accountability-not independent courts-remain the basic mechanisms of supervision and redress. Even if administrative law in European nations is strengthened, it is likely to be implemented through administrative tribunals, part of the executive branch, not by means of costly, adversarially-structured litigation in courts of general jurisdiction, as is the case in the United States. ${ }^{76}$

Parliamentary structures are another source of resistance. Between elections, European national governments are dominated by a relatively cohesive majority

\footnotetext{
${ }^{75}$ Deirdre Curtin, 'The Province of Govermment: Delimiting the Direct Effect of Directives in the Common Law Context', Eumpian Law Reviev (April 1990) 195.

${ }^{36}$ Thus even the expanded French administrative review system is expeditious and substantively-oriented, rather than adversarial and legalistic. L. Neville Brown \& John S. Bell, French Administrative Law, 4th Ed (Oxford: Clarendon Press, 1993). In the above-mentioned study of land use disputes in Montpellier, Freiburg, and New Haven, it is only in New Haven that the author found that lawyers were ubiquitous-as representatives of developers, as advisers to land use control agencies, and as spearheads of local neighbourhood groups opposed to development, Sellers, 'Litigation as a local Political Resource'.
} 
political party or a majority coalition. In the United States, in contrast, adversarial legalism flourishes because governmental power is fragmented. Republican chief executives share power, and clash with, Democratic legislatures (or vice versa). Within political parties, legislative committee chairmen fight for their own favourite policies, regardless of the preferences of political party leaders. Political entrepreneurs push through statutory amendments, draconian penal laws, and special tax provisions without regard to administrative concerns. The Trial Lawyers Association spends vast sums on campaign contributions and on lobbying against legislation designed to reform tort law. Legislation, accordingly, is the product of negotiation and logrolling. It often is incoherent, leaving crucial policy choices to be worked out by the Courts in subsequent litigation. ${ }^{77}$

Politically-unified European parliamentary majorities, in contrast, are relatively immune to these political sources of adversarial legalism. Generally speaking, they draft laws with less concern for interest group money and individual legislators' electoral ambitions-and with more attention to bureaucratic experts, corporatist councils, and justice ministries. Without a politically potent trial lawyer's bar to worry about, European legislatures can meet public demands for rights and participation not by encouraging litigation but, as in the Netherlands, by elaborating a variety of informal dispute-resolution forums. ${ }^{78}$

The third and perhaps the most important source of resistance to adversarial legalism is the inherent reflexiveness of human political and legal systems. In the global communications village, political and legal élites study the experiences of other nations; they perceive trends and their undesirable side effects. The negative side of American adversarial legalism is not hidden from European observers. Every adversarially-tinged proposed legal reform must deal with the warning, 'Be careful or we will end up like the United States!'

Hence it is difficult to believe that European Governments ever would adopt adversarial methods of compensating injured persons that are so obviously wasteful and erratic as the American tort law system. ${ }^{79}$ Nor are European Governments likely to adopt environmental laws that rely heavily on litigation, such as the American 'Superfund' law for cleaning up chemical waste sites, since such methods have been shown to be not only inefficient but ineffective. ${ }^{80}$

Indeed, one might just as well expect some reverse learning. American political and legal élites may realize that American adversarial legalism is so inefficient and costly, particularly in areas such as tort law, that they will seek to emulate European legal or social insurance approaches, selectively displacing the tortjury-trial system for some kinds of injuries. Reacting to corporate fears of litigation, state law in recent years has restricted individual corporate officers'

\footnotetext{
${ }^{77}$ For an excellent comparison of statutory lawmaking in Great Britain and the United States, see Atyah \& Summers, Form and Substance in Anglo-American Law, ch 11.

${ }^{78}$ Erhard Blankenburg, 'The Infrastructure for Avoiding Civil Litigation: comparing Cultures of Legal Behavior in the Netherlands and West Germany', 28 Law and Society Review 789 (1994).

${ }^{79}$ See Stephen Sugarman, Doing Away with Personal Injury Law (NY: Quorum Books, 1989).

${ }^{80}$ See Thomas Church \& Robert Nakamura, Cleaning Up the Mess: Implementation Strategies in Supevfund (Washington: Brookings Institute, 1993); Marc Landy \& Mary Hague, "The Coalition for Waste: Private Interests and the Superfund' in Greve \& Smith (eds) Environmental Politics (NY: Praeger, (1992).
} 
and directors' liability for poor business judgement or disappointing earnings. ${ }^{81}$

This is not to say that traditional European legal folkways are unchangeable. In some policy realms, American adversarial legalism will have some appeal on straightforward policy-analytical grounds. Continued international economic integration will probably produce more movement toward American styles of contracting, commercial dispute-resolution, corporate financial regulation, controls on private pension funds, and environmental regulatory enforcementpartly because they often are well-adapted to a highly competitive, privatized economy ${ }^{82}$ Similarly, European reformers, plugged into the Internet and American TV news, probably will continue to lobby for some of the individual legal rights that American adversarial legalism is so prolific at inventing, such as rights against spousal abuse, discrimination, sexual harassment, unwanted exposure to tobacco smoke, and so on -although it is more likely that European legal systems will adopt American norms than adversarial American enforcement methods.

On the other hand, in the broad spheres of law less affected by and essential to economic integration-such as judicial and administrative procedures, criminal justice, and family-related disputes-the pressures for emulating American ways are weaker and the arguments for doing so are highly disputable; here the dikes of traditional legal culture are likely to hold firm.

Finally, however, it should be noted that adversarial legalism always will hold some attractions for entrepreneurial lawyers, political and social underdogs, environmentalists, civil libertarians, and advocates of political openness. Hence European legal élites regularly and quite properly will be confronted with demands for adversarial legalism. I suggest, therefore, that they should worry about it in the sense of thinking about how to capture its some of its benefits without incurring all its costs. If Europeans take this advice, they will have some of the same worries as Americans-and their solutions to those worries may be of considerable value to legal reformers in the United States.

\footnotetext{
81 Romano, 'Corporate Governance ... .; William Bratten, 'Public Values, Private Business, and U.S. Corporate Fiduciary Law', in Joseph McCahery, Sol Piccioto, \& Colin Scott (eds) Corporate Control and Accountability: Changing Structures and the Dynamics of Regulation (1993); Jonathan Clarkham, Keeping Good Company: $A$ Study of Conporate Governance in Five Countries (1994) 357.

However, European Governments that are intent, for political reasons, on pursuing economic growth, boosting domestic employment, and other aspects of industrial policy are likely to continue methods of economic regulation that retain a strong discretionary role for governmental steering authority-and hence to limit legal restrictions on and judicial review of policy making and implementation. See Stephen Vogel, Freer Markets, More Rules.
} 
HeinOnline -- 17 Oxford J. Legal Stud. 1841997 